
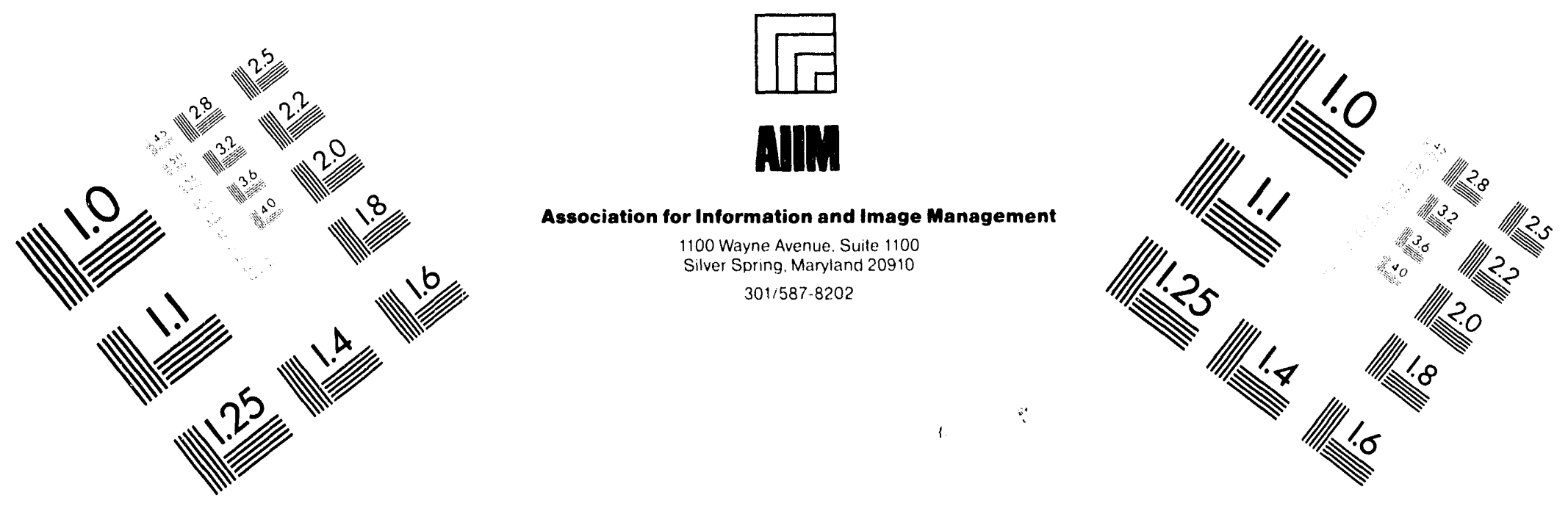

\title{
Centimeter
}

1

Inches
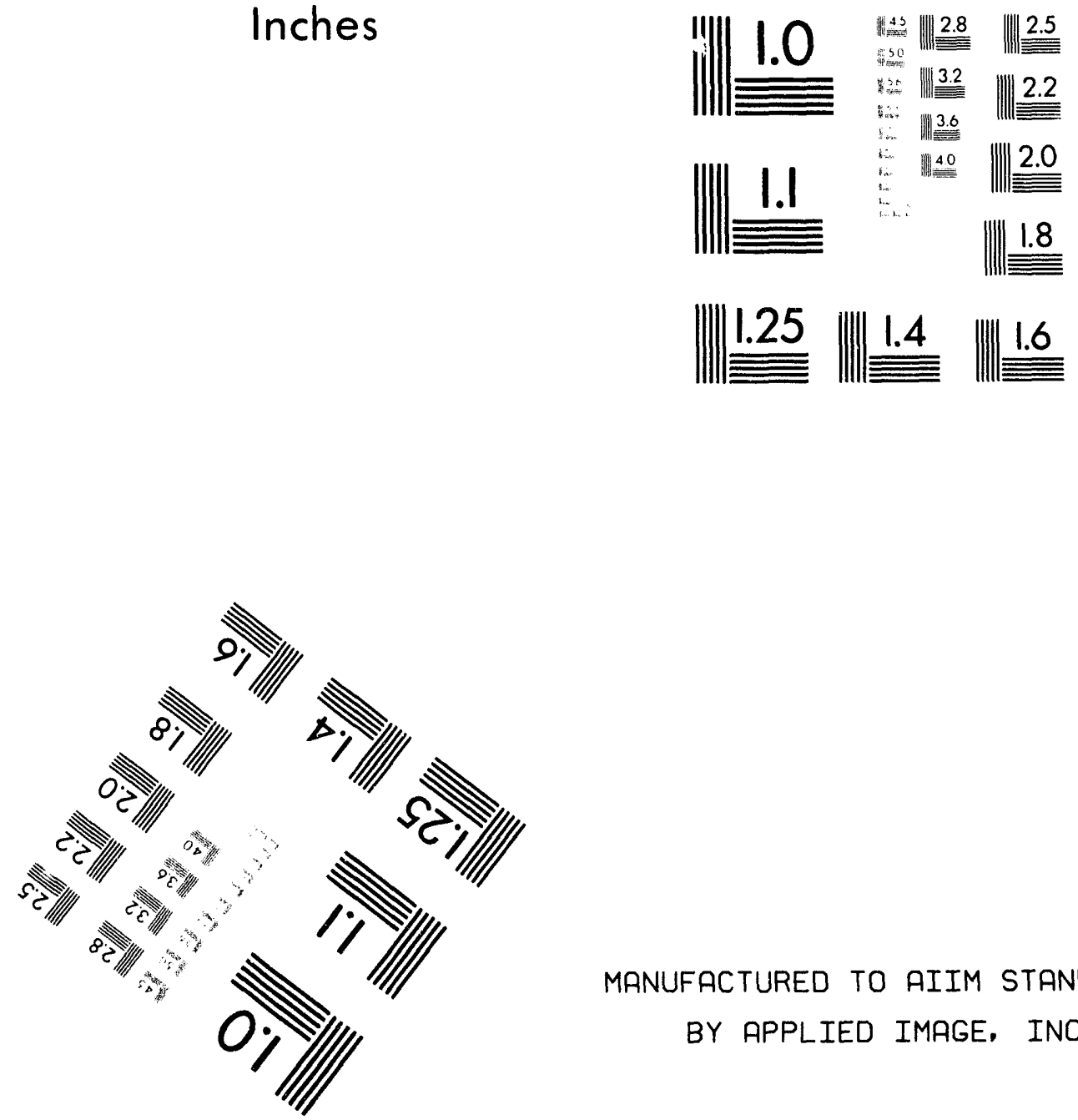

MANUFACTURED TO AIIM STANDARDS

BY APPLIED IMAGE, INC.

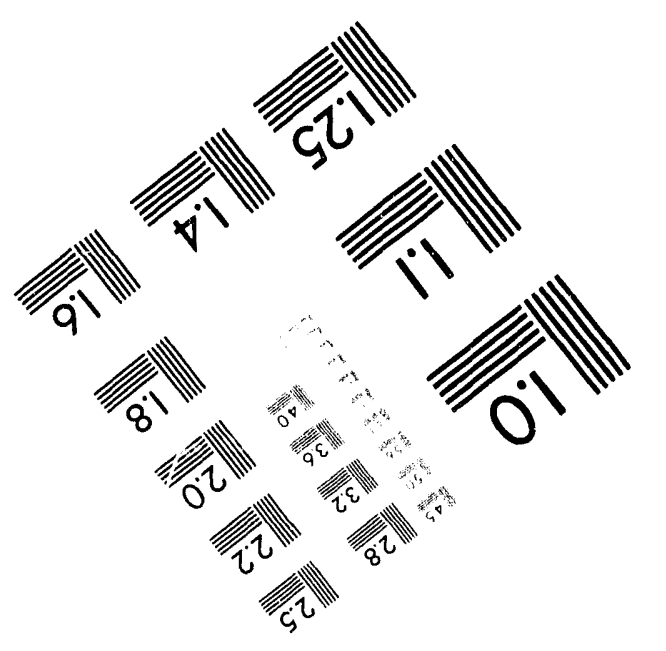



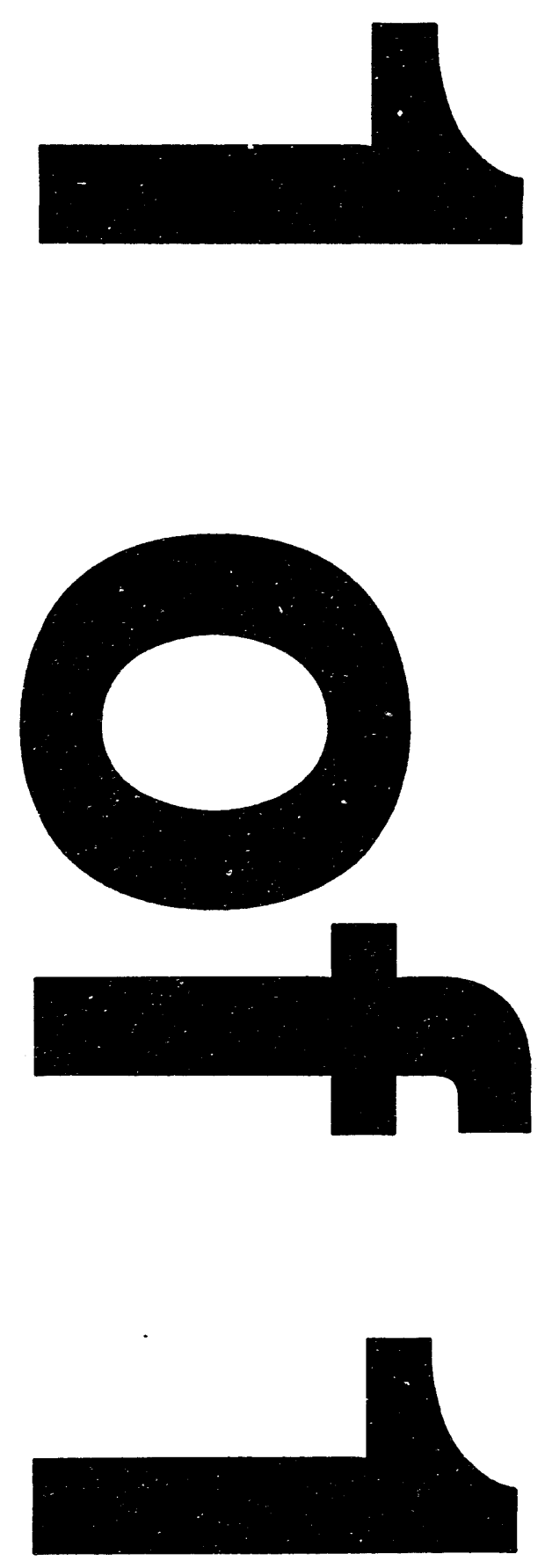


\section{District Heating and Cooling Market Assessment}

by A.P.S. Teotia, D.E. Karvelas, E.J. Daniels, and J.L. Anderson

Energy Systems Division,

Argonne National Laboratory, 9700 South Cass Avenue, Argonne, Illinois 60439

June 1993 (revised, April 1994)

Work sponsored by United States Department of Energy,

Office of Utility Technologies, under contract W-31-109-Eng-38

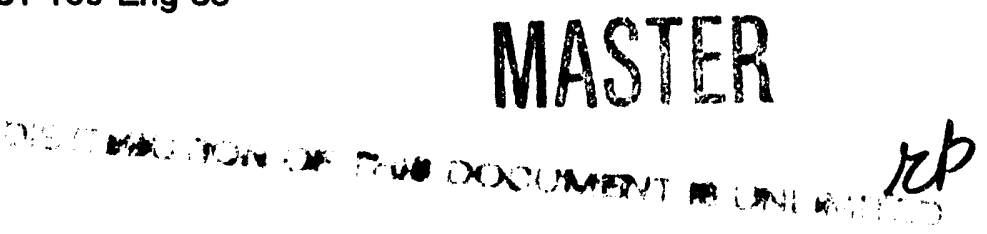




\section{Contents}

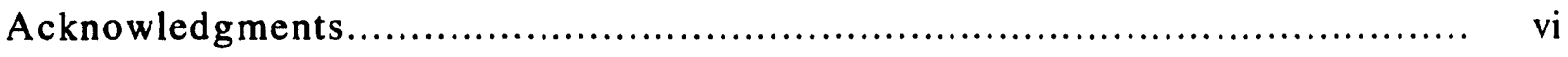

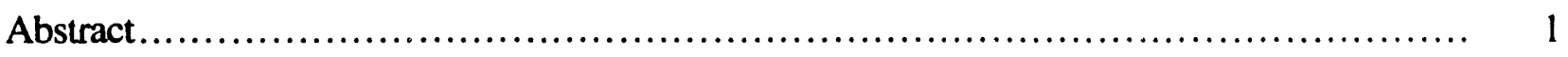

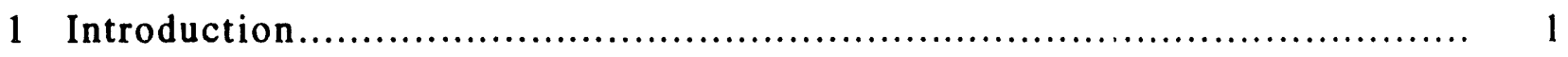

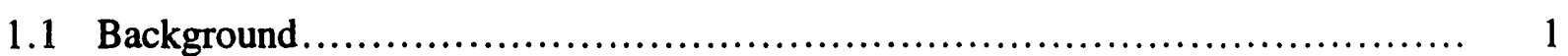

1.2 Objectives of the DHC Market-Potential Project............................. 4

1.3 Report Structure ........................................................ 4

2 Approach for Estimating DHC Market Potential ............................... 5

2.1 Selection of DHC System Types...................................... 5

2.2 DHC Data Collection....................................................... 6

2.3 Finalization of Scope of DHC Forecasting Task............................. 6

3 Estimation of DHC Historical Market ........................................ 8

3.1 Industry-Sponsored DHC Survey Data ................................ 8

Data from DOE/EIA Commercial Buildings Energy
Consumption Surveys $\ldots \ldots \ldots \ldots \ldots \ldots \ldots \ldots \ldots \ldots \ldots \ldots \ldots \ldots \ldots \ldots \ldots \ldots \ldots \ldots \ldots \ldots \ldots \ldots \ldots \ldots \ldots \ldots \ldots \ldots \ldots \ldots \ldots$

3.3 DHC Data Sources Used ..................................................... 9

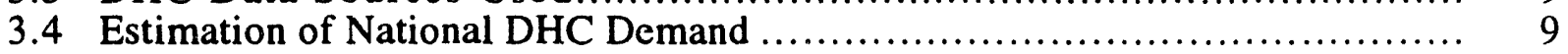

3.5 Estimation of DHC Demand by Key Market Segments ..................... 12

4 DHC Market Projection Methodology ...................................... 18

4.1 Overview of Available Forecasting Methodologies .......................... 18

4.2 Selected Methodology .................................................... 18

5 Characterization of DHC Base Case ....................................... 21

5.1 DHC Technology and End-Use Market Assumptions under the

Base Case ................................................................. 21

5.1 .1 Technology Improvements............................................. 21

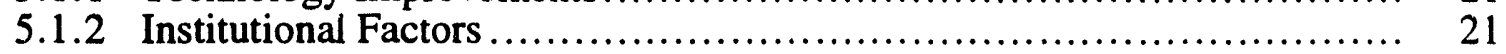

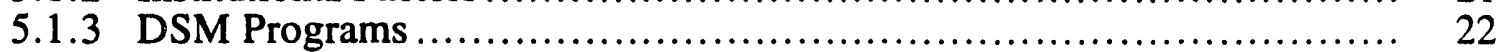

5.2 Projections of DHC Model Exogenous Variables under the Base Case ......... 23

5.2.1 Commercial-Building Floor Space ................................... 23

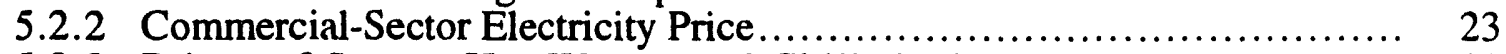

5.2.3 Prices of Steam, Hot Water, and Chilled Water...................... 23

5.2.4 Other Exogenous Variables............................................ 24

6 DHC Market Projections under the Base Case...................................... 25

6.1 National Market Projections............................................... 25

6.2 Market Projections for Selected DHC Systems............................. 26

6.2 .1 DHC System Type I............................................... 26

6.2.2 DHC System Type II................................................... 26

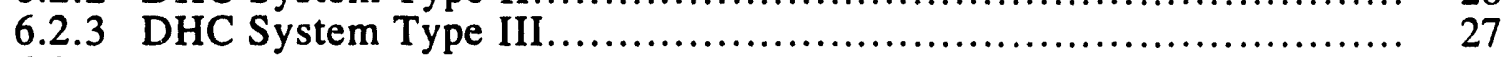

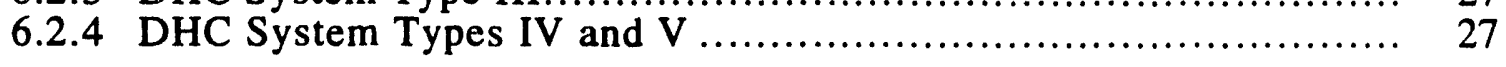




\section{Contents (Cont.)}

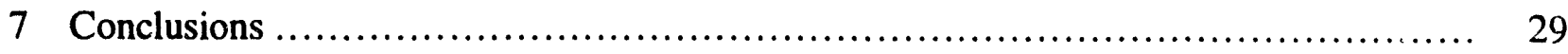

7.1 Overview and Scope ......................................................... 29

7.2 Application of the Model.................................................. 30

7.3 Principal Findings................................................................. 30

7.4 Limitations and Utility of the Model ..................................... 30

8 References .................................................................... 32

Appendix: Development of DHC Models......................................... 35

\section{Tables}

1 Estimated U.S. Consumption of District Heat and Chilled Water in Commercial Buildings, 1989 .....

2 Estimated Energy Intensity of District Steam, Hot Water, and Chilled Water in Commercial Buildings, 1989

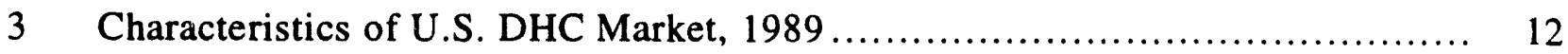

4 DHC Energy Consumption by Census Region, 1989......................... 13

5 DHC Energy Consumption by Type of Building Activity, 1989 _............... 14

6 DHC Energy Consumption by Building Floor Space, 1989.................... 14

7 DHC Energy Consumption by Building Age, 1989 ............................ 15

8 DHC Energy Consumption by Metropolitan Location, 1989..................... 15

9 DHC Energy Consumption by Multibuilding Facility Status, 1989................ 16

10 DHC Energy Consumption by Building Ownership, 1989 .................... 16

11 DHC Energy Consumption by DSM Status, 1989............................... 17

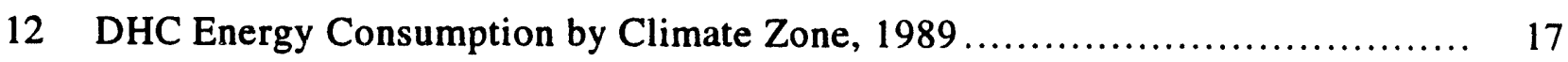

13 DHC Market Projections under the Base Case .................................. 25

14 DHC Energy Consumption Projections for Educational, Health-Care, and Government-Owned Buildings ............................................... 26

15 DHC Energy Consumption Projections for Multibuilding Facilities in Metropolitan Areas and Those Served by Large DHC Systems ................. 27

16 Estimated Market Potential of DHC System Type IV .......................... 28 


\section{Tables (Cont.)}

A.1 OLS Parameter Estimates for District Steam Demand Model .................. 37

A.2 OLS Parameter Estimates for District Hot-Water Demand Model ................ 37

A.3 OLS Parameter Estimates for District Chilled-Water Demand Model ............. 38 


\section{Acknowledgments}

This report is based on a research project sponsored by the U.S. Department of Energy (DOE), Office of Utility Technologies. The support of DOE research program manager Floyd Collins is gratefully acknowledged. Reviews and comments were provided by Robert Brewer, director of the Utility Systems Division at DOE's Office of Energy Management; Eugene Burns, Energy End-Use and Integrated Statistics Division at DOE's Energy Information Administration; Gordon Bloomquist, Hydro-Thermal Program Specialist, Resource and Policy Division, Washington State Energy Office; and by Thomas Marciniak, manager of the Industrial and Power Technology Section, Energy Systems Division, at Argonne National Laboratory (ANL). Eugene Burns also provided estimated standard errors for selected variables, including consumption of steam, hot water, and chilled water, from the 1989 Commercial Buildings Energy Consumption Survey.

The authors extend their thanks to ANL staff members Floyd Bennett, Kevin Brown, Leslie Crosser, and Vicki Skonicki for their editorial and word-processing assistance. The final responsibility for the content of this report remains with the authors, and any opinions expressed herein are solely theirs. 


\title{
District Heating and Cooling Market Assessment
}

by

\author{
A.P.S. Teotia, D.E. Karvelas, E.J. Daniels, and J.L. Anderson
}

\begin{abstract}
For more than 10 years, the U.S. Department of Energy (DOE) has supported research on and development of district steam, hot-water, and chilledwater systems in the residential and commercial sectors. In 1991, DOE sponsored a research project at Argonne National Laboratory (ANL) to reestimate the national market for district heating and cooling (DHC) systems to the year 2010. ANL had previously developed a DHC market-penetration model and used it to project future market penetration. The first step in the project was to conduct a literature search to identify major data sources on historical DHC markets and any past studies on the future market potential of DHC systems. On the basis of an evaluation of the available data and methodologies for estimating market penetration of new technologies, it was concluded that ANL should develop a new econometric model for forecasting DHC markets. By using the 1989 DOE/Energy Information Administration Commercial Buildings Energy Consumption Surveys (CBECS) public-use-tape data, a model was estimated for steam, hot-water, and chilled-water demand in the buildings surveyed. The model provides estimates of building steam, hot-water, and chilled-water consumption and expenditures between now and the year 2010. The analysis shows that the total U.S. market for district steam, hot water, and chilled water could grow from 0.8 quadrillion British thermal units (quad) in 1989 to 1.0 quad by 2000 and 1.25 quad by 2010 . The demand for chilled water could nearly double in the forecast period, and its share could approach one-third of the total DHC market. This model, and the results, should be of use to policymakers, researchers, and market participants involved in the planning and implementation of community-based, energy-conserving, and environmentally beneficial energy systems.
\end{abstract}

\section{Introduction}

\subsection{Background}

District heating and cooling (DHC) systems have been in use in the United States for more than 100 years. They are more energy-efficient than conventional systems, and their use results in lower greenhouse gas emissions. Historically, DHC systems have been used primarily in a limited number of urban areas, military installations, and medical and educational institutions. Although 
DHC systems supply a small percentage of the total demand for space heating and cooling in the United States, the capital investment in these systems is significant.

In the past, very little information was available on the extent of the DHC market in the United States. The lack of knowledge concerning DHC market estimates, characteristics, and growth potential has made it difficult both for the industry to plan and project capital investment needs and for the federal government to plan and prioritize activities aimed at enhancing the market penetration of DHC systems.

Until 1986, to a large extent, the DHC data that did exist were scattered, difficult to correlate with other data, and often unreliable. In 1986, the U.S. Department of Energy's Energy Information Administration (DOE/EIA) conducted the first DHC survey, which represented a serious effort to collect data on the DHC market in the United States. In the last several years, several trade associations, such as the International District Heating and Cooling Association (IDHCA), have undertaken surveys to estimate the extent of DHC in the United States, but their surveys have concentrated primarily upon each trade association's membership; as a result, their surveys have represented only a segment of the national DHC market.

The U.S. Department of Energy has been a major contributor in the development of DHC systems and in the revitalization of older systems. Starting in the second half of the 1970s, DOE funded DHC activities for identifying and developing economically viable, energy-conserving, community-based energy systems. It has supported research into and development of advanced district steam, hot-water, and chilled-water systems in the residential and commercial sectors. The DOE initiative for advancing the use of DHC systems in the United States, together with high energy prices in the 1970 s, induced considerable interest in the DHC concept. As a result, a number of communities developed modern DHC systems. From 1970 to 1980, there was no significant growth in demand for district heating (International District Heating Association 1983), but in the 1980s, with the newer and revitalized systems coming on line, DHC market penetration started to increase. In particular, rapid growth has been seen in district cooling.

The Department of Energy's DHC research program has funded research projects in ice storage, ice slurries, and friction-reduction additives for thermal-distribution systems. These research efforts could have a major impact in the future, increasing the efficiency and costeffectiveness of DHC systems. A preliminary economic assessment of the ice-water slurry research, conducted at ANL and funded by DOE, indicates that when a $30 \%$ ice slurry is used in place of chilled water, the cost of district-cooling (DC) distribution systems may be reduced by as much as 50\%. This and other technical innovations are likely to reduce the up-front capital cost of new DC systems and consequently to increase the economic feasibility of developing new DC systems. Research in the development of friction-reducing additives is likely to yield similar benefits for DHC hydronic systems.

In the 1980s, institutional changes had a major impact on the DHC industry. Ownership of some district-heating (DH) systems changed hands as some electric utilities sold their DH systems to the private sector. DC market penetration started to grow in the 1980s as environmental 
regulations, electric rate schedules, and demand-side-management (DSM) programs sponsored by electric utilities enabled DC systems to become more competitive. The phasing out of chlorofluorocarbons (CFCs) and more strict future environmental regulations are likely to increase the market penetration of DC systems, but the high up-front capital cost for the construction of new systems will continue to impede their development.

Cogeneration and independent power production have penetrated the market significantly since 1980. Provisions of the Public Utility Regulatory Policy Act (PURPA) of 1978 and the Energy Policy Act of 1992 have assisted this growth. The DOE/EIA, in its Annual Energy Outlook 1992, projects that $65 \mathrm{GW}$ of the $249 \mathrm{GW}$ of additional electric generation required between 1990 and 2010 will be supplied by nonutility-owned companies (DOE/EIA 1992a). These trends are likely to continue to affect the competitiveness of DHC, and particularly the growth of DC markets, in a positive way.

The DHC markets were last estimated in 1982 by Argonne National Laboratory (Teotia and Poyer 1983). These estimates were obtained with the use of the DHC market-penetration model developed by ANL between 1979 and 1981 (Teotia, Davis, and Poyer 1981).

In 1991, DOE sponsored a research project at ANL for reestimating total U.S. market penetration of these district-systems to the year 2010. The DHC market penetration was to have been estimated by using either the DHC market-penetration model developed earlier by ANL or a more appropriate methodology. In addition, if feasible, the market penetration was to be estimated for five selected DHC applications and end-use markets (see Section 2.1).

Argonne conducted a literature search to identify major data sources on historical DHC markets and any past studies on the future market potential of DHC systems. Extensive related information was obtained from government and industry sources, but the projections made by ANL in 1982 remained the most recent and reliable. Major improvements were noted in the availability of historical data on energy consumption and expenditures for district steam, hot water, and chilled water, through DOE/EIA Commercial Buildings Energy Consumption Surveys (CBECS). No other data source was identified for national estimates of the DHC market.

On the basis of an evaluation of the available data and methodologies for estimating market penetration of new technologies, ANL investigators concluded that a new econometric model for forecasting DHC markets over a 20-year period should be developed. A linear regression model was used to develop each of the three equations for steam, hot-water, and chilled-water demand in the buildings surveyed. The model was developed by using the 1989 CBECS public-use tape data (DOE/EIA 1992b). 


\subsection{Objectives of the DHC Market-Potential Project}

In this study for estimating the current DHC market and projecting its growth, a major effort was made to define the scope and the approach for accomplishing the goals of this difficult project. After discussing and analyzing various approaches for forecasting the DHC market growth, it was agreed that the forecasting methodology would be defined after ANL had collected and analyzed DHC market data. The agreed-upon work scope of this study also required that ANL, subject to the availability of historical (statistical) market data, would develop market-growth projections for five specific DHC-system types, which were characterized by service area, system output, and ownership arrangements (see Section 2.1).

On the basis of ANL's previous DHC market-penetration studies, the investigators recognized from the beginning of this research project that the DHC industry contains many segments, and some segments have limited resources for collecting and maintaining statistical DHC market data. The lack of data for some segments constrained the ability of ANL to provide a credible market assessment for some of the systems and markets listed in Section 2.1. Because of these limitations, ANL decided to document and report, as a minimum required deliverable, whatever market-related data were collected for each system type. Where studies already conducted by industry groups had adequately described each system's market share and market potential, the results of such studies, after review by ANL, were considered to constitute an acceptable deliverable for describing a systems market.

\subsection{Report Structure}

The remainder of the report is divided into seven sections. Section 2 discusses the overall approach taken for estimating market potential of selected DHC system types. Section 3 outlines the DHC historical market, based on available data. Section 4 discusses the methodology used in estimating DHC market penetrations. Section 5 characterizes the DHC base case. Section 6 presents the estimated DHC market projections under the base case. Section 7 discusses the major conclusions of the report. Section 8 lists sources of information referenced in the report. 


\section{Approach for Estimating DHC Market Potential}

This section discusses the overall approach taken for estimating the market potential of DHC systems. Section 2.1 describes the selected DHC system types for which market potential is estimated. Section 2.2 indicates the approach taken for DHC data collection. Section 2.3 discusses the final scope of the DHC market-forecasting task in view of the available DHC historical data and models.

\subsection{Selection of DHC System Types}

District heating and cooling systems have been in use in the United States for more than 100 years. Historically, DHC systems have been used primarily in a limited number of urban areas, in military installations, and in medical and educational facilities. The type of energy services provided by existing DHC systems is determined by institutional factors, local competing energy-supply options, and financial factors. Ownership arrangements have also affected the system configuration that is employed. Facilities, such as military bases and colleges, that are owned and occupied by a single organization usually do not market DHC services to facilities owned by other organizations. Municipal systems typically market services to buildings that have a variety of owners.

Steam and hot-water systems currently employed in the United States have distinct advantages and disadvantages. Historically, DH systems were based on steam because power plants (the heat source) were located close to urban areas and were able to provide greater quantities of heat to centralized business districts and residential communities. Hot-water systems were developed primarily in Europe. These systems operated at much lower temperatures, so they could take advantage of the many low-temperature waste-heat resources available in a typical community. Distribution costs for hot-water systems are lower than those for steam systems, because of the lower temperatures, and with hot-water systems heat can be transmitted over much longer distances than are feasible for steam systems. Some of these European-developed DH systems have been used in the United States - for example, in St. Paul, Minnesota.

More recently, some of the factors that have limited DHC growth in the past have changed through federal legislation and market factors. As a result, cogeneration and independent power production have emerged as economically viable energy-production options. These combined heating and power-generating plants serve industrial thermal loads, space heating and cooling, and electrical needs. Within the last 10 years, the provisions of the PURPA of 1978 and lower natural gas prices have been major factors in the explosive growth of independent power production and cogeneration.

On the basis of discussions between representatives of the DOE and the IDHCA, five DHC system types were selected for the analysis of the DHC market. These five DHC system types 
represent most of the typical systems currently employed by the DHC industry. These system types are defined as follows:

I. DHC systems, with or without cogeneration but with no electricity sales to grid, typically serving educational, medical, and government building complexes;

II. Large DHC systems serving multiple end-users in urban areas;

III. District-cooling systems;

IV. Independent Power Producers (IPPs) and Qualifying Facilities (QFs) under PURPA, with cogeneration facilities and grid connection; and

V. Medium-size DHC systems that derive thermal energy from utility-owned or municipally owned power plants retrofitted for cogeneration and serving multiple end-users in urban areas.

\subsection{DHC Data Collection}

ANL conducted a literature search to identify major data sources on historical DHC markets and any past studies on the future market potential of DHC systems. Extensive related information was obtained from government and industry sources, including DOE's Energy Information Administration (DOE/EIA 1989); Data Resources, Inc. (DRI 1992); the International District Heating and Cooling Association (IDHCA 1989); the Electric Power Research Institute (EPRI 1990); RCG/Hagler, Baily, Inc. (RCG 1990); and the Gas Research Institute (GRI 1982). The collected information verified that no research providing national market projections of DHC systems had been undertaken during the last 10 years; the projections made by ANL in 1982 remained the most recent. Nevertheless, major improvements were noted with regard to the availability of historical data on energy consumption and expenditures, and space served by district steam, hot water, and chilled water, through DOE/EIA Commercial Buildings Energy Consumption Surveys (CBECS) conducted for 1979, 1983, 1986, and 1989. No other data source was identified for national estimates of the DHC market.

\subsection{Finalization of Scope of DHC Forecasting Task}

Upon analyzing available data and methodologies for the underlying DHC market-forecasting task, ANL judged that the best approach would be to develop a new econometric model that could determine the consumption of district steam, hot water, or chilled water in a building as a function of its own price; the price of competing fuels, such as electricity; selected building characteristics, such as heated and cooled area; and related variables. On the 
basis of the availability of data, Argonne decided to develop models for steam, hot water, and chilled water by using information in the 1989 CBECS database. This survey consists of about 6,000 observations for commercial buildings. Further discussion of this survey is provided in Section 3.2 . 


\section{Estimation of DHC Historical Market}

This section provides the estimated historical market penetration of DHC systems. Section 3.1 discusses the DHC survey data obtained by the IDHCA, and Section 3.2 describes the CBECS data prepared by DOE/EIA. Section 3.3 highlights selected data from these sources to be used for estimating DHC market potential. Section 3.4 provides estimated DHC national demand in 1989, and Section 3.5 disaggregates the historical demand by key market segments.

\subsection{Industry-Sponsored DHC Survey Data}

Starting in 1986, the IDHCA surveyed its membership as to market characteristics, system types, and system performance. Although these data provide a good characterization of municipal systems, they do not provide a good representative sample of other segments, sucn as DHC systems that serve military bases and college campuses. Argonne analyzed results of these surveys as part of the present research effort and utilized the information, as far as possible, to estimate market penetration of DHC systems. Also, ANL contacted some DHC-industry members and solicited information about current and future institutional and economic issues facing the industry.

\subsection{Data from DOE/EIA Commercial Buildings Energy Consumption Surveys}

The DOE/EIA has conducted CBECS for 1979, 1983, 1986, and 1989. Each survey encompasses several thousand observations on energy consumption and expenditures in U.S. commercial buildings.

The DOE/EIA has collected data on steam systems since its first survey in 1979 and on hotwater and chilled-water systems since its third survey in 1986. In its report (DOE/EIA 1992c), the DOE/EIA notes that the 1979 and 1983 CBECS asked for data about purchased steam, the 1986 CBECS (DOE/EIA 1989) asked for data about purchased and nonpurchased steam and hot water, and the 1989 CBECS asked for data about steam or hot water piped into the building. The DOE/EIA also noted that the quantities reported for district heating (steam and hot water) have been increasing with each CBECS iteration. However, the increase may be more a result of better identification than any actual increase in use. For example, the 1989 survey has additional information on multibuilding facilities.

The DOE/EIA expects estimates from future CBECS to remain in the range of the 1989 CBECS estimates (DOE/EIA 1992c). A similar pattern was noted by ANL in the analysis of the chilled-water data from the 1986 and 1989 CBECS data tapes. For these reasons, the 1989 CBECS was selected as one of the key data sources for the analysis of the historical market for steam, hot water, and chilled water. 


\subsection{DHC Data Sources Used}

On the basis of the available data sources discussed in Sections 3.1 and 3.2, the 1989 CBECS was selected to provide historical data for consumption of steam, hot water, and chilled water in U.S. commercial buildings. Note that the CBECS do not collect any information on types of systems delivering steam, hot water, and/or chilled water to a building. Therefore, DHC markets could not be estimated by system types from CBECS data alone. For these cases, ANL supplemented the CBECS data with information from an industry survey prepared by the International District Heating and Cooling Association in 1989 (IDHCA 1989). This survey, which included data from 63 companies, provided such plant-specific statistics as type and size of systems and sales of generated steam, hot water, chilled water, and cogenerated electricity. Because the IDHCA survey is not a statistical sample of all DHC industry in the United States, its data could not be used for estimating the national DHC maiket. The authors agree with the following DOE/EIA comment (DOE/EIA 1993): "The CBECS Energy Suppliers Survey remains the best source for estimates of district heating and cooling supplied to commercial buildings." Thus, the 1989 CBECS is the primary source of data for estimating the DHC market in the commercial sector.

Argonne received a 1989 CBECS public-use data tape from DOE/EIA in June 1992. The data set included 5,876 records pertaining to all commercial buildings; 539 records were for buildings using steam, hot-water, or chilled-water systems. Highlights of the analysis of the 1989 data are discussed in the following section.

\subsection{Estimation of National DHC Demand}

It is standard practice to provide estimated mean and standard errors for all statistical variables. The authors' objective was to include the relative standard errors (RSE = standard error/mean $\times 100$ ) along with the estimated mean values of all key variables. However, the estimation of RSEs is complex for all estimates based on CBECS data. In this regard, a quotation from the DOE/EIA report follows: "The CBECS used a list-supplemented, multistage area sample design of such complexity that it is virtually impossible to construct an exact algebraic expression for estimating variances. In particular, convenient formulas based on an assumption of simple random sampling, typical of most standard statistical packages, are entirely inappropriate for the CBECS estimate" (DOE/EIA 1992c). Instead, DOE/EIA used a "jackknife" replication method for estimating sample variances.

ANL did not receive the CBECS data until June 1992. Because of the time and cost required for developing or procuring the necessary computer software to estimate RSEs, ANL requested and received assistance from DOE/EIA in estimating RSEs for district chilled-water consumption and energy intensity (measured in British thermal units per square foot, Btu/ $\mathrm{ft}^{2}$ ) (DOE/EIA 1992d, 1994). It was also decided to use the published RSEs for the combined category of district heat (steam and hot water) (DOE/EIA 1992c). The DOE/EIA report does not provide separate estimates for steam and hot water. 
The number of observations for either district hot water or chilled water in the CBECS data set is much lower than that for district steam. Therefore, the relative standard errors in data for steam are expected to be the lowest among these three district system types. Because of the high relative standard errors, the chilled-water and hot-water data in this report should be used with extra care.

Table 1 provides the estimated national consumption of district heat and chilled water delivered to buildings. In this study, ANL converted ton-hours to British thermal units by using a straight conversion factor of 12,000 Btu per ton-hour; the public-use tape does not contain any chilled-water estimates in Btu. In 1989, the district heat consumption was $585 \times 10^{12} \mathrm{Btu}$. The 95\% confidence intervals can be determined by adding/subtracting two standard errors to the value of the mean. Therefore, with $95 \%$ confidence, district heat consumption was between 393 and $777 \times 10^{12} \mathrm{Btu}$. The consumption of district chilled water, $220 \times 10^{12} \mathrm{Btu}$, was found to be lower than that of district heat. As expected, consumption of district chilled water (relative standard error of about $42 \%$ ) had greater variability than that of district heat (RSE of about $16 \%$ ). With $95 \%$ confidence, the district chilled-water consumption was between 36 and $404 \times 10^{12}$ Btu. This estimate for chilled water should be used with caution. Total consumption of district steam, hot water, and chilled water is estimated to be $805 \times 10^{12} \mathrm{Btu}$, which is a significant part (about $14 \%$ ) of the total consumption of all major fuels in the commercial sector (DOE/EIA 1989).

Energy intensity $\left(10^{3} \mathrm{Btu} / \mathrm{ft}^{2}\right)$ is another very useful way of analyzing energy demand in a commercial building. This indicator is provided for district systems in Table 2 . Energy intensity is estimated to be highest for district chilled water, $114 \times 10^{3} \mathrm{Btu} / \mathrm{ft}^{2}$, followed by $92 \times 10^{3}$ for district steam, $58 \times 10^{3}$ for district hot water, $50 \times 10^{3}$ for natural gas, $45 \times 10^{3}$ for electricity, and $28 \times 10^{3} \mathrm{Btu} / \mathrm{ft}^{2}$ for fuel oil (DOE/EIA 1992c, 1994). An important observation is made with regard to the quality of district steam, hot-water, and chilled-water estimates. The relative standard errors are smaller for energy-intensity indices than for energy-consumption indices (Tables 1 and 2). Therefore, the concept of energy intensity is used in explaining building consumption of DHC energy sources through the newly developed model discussed in the Appendix.

Table 3 provides estimates made on the basis of an analysis of 1989 CBECS computer-tape data about the number of buildings, floor space, energy consumption, energy expenditures, and average energy prices for district steam, hot water, and chilled water. Among others, these data were compared against IDHCA data (IDHCA 1989). One or more district system types were employed in $106 \times 10^{3}$ buildings, with floor space of $6,945 \times 10^{6} \mathrm{ft}^{2}$, in the United States. The energy consumption and expenditures were estimated to be $487 \times 10^{12} \mathrm{Btu}$ (0.487 quad) and $\$ 3.2$ billion for steam, $98 \times 10^{12} \mathrm{Btu}(0.098 \mathrm{quad})$ and $\$ 0.6$ billion for hot

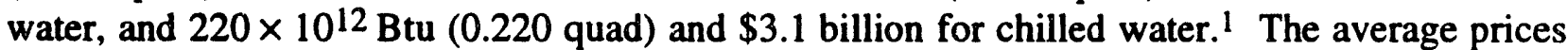
for steam and hot water were very close, but the average price for each of these was approximately half that of chilled water. Among the three district system energy sources, the energy intensity is highest for chilled water and lowest for hot water.

11 quad $=10^{15}$ Btu. 
TABLE 1 Estimated U.S. Consumption of District Heat (Steam and Hot Water) and Chilled Water in Commercial Buildings, 1989a

\begin{tabular}{lccc}
\hline $\begin{array}{c}\text { Energy } \\
\text { Source }\end{array}$ & $\begin{array}{c}\text { Mean } \\
\left(10^{12} \mathrm{Btu}\right)\end{array}$ & $\begin{array}{c}\text { Standard Error } \\
\left(10^{12} \mathrm{Btu}\right)\end{array}$ & $\begin{array}{c}\text { Relative } \\
\text { Standard } \\
\text { Errorb }\end{array}$ \\
\hline District heat & $585^{\mathrm{c}}$ & $(96)^{\mathrm{d}}$ & 16 \\
District chilled water & $220^{\mathrm{e}}$ & $(92)^{\theta}$ & 42 \\
All DHC systems & 805 & - & - \\
\hline
\end{tabular}

a Source: DOE/EIA (1989) (CBECS public-use tape), unless otherwise specified.

b Relative standard error $=($ standard error $/$ mean $\times 100)$.

c Source: DOE/EIA (1992c).

d Converted from the relative standard errors given in the above DOE report.

- Estimated by DOE/EIA for ANL, July 1992.

TABLE 2 Estimated Energy Intensity of District Steam, Hot Water, and Chilled Water in Commercial Buildings, 1989a

\begin{tabular}{lccc}
\hline \multicolumn{1}{c}{$\begin{array}{c}\text { Energy } \\
\text { Source }\end{array}$} & $\begin{array}{c}\text { Mean } \\
\left(10^{3} \mathrm{Btu} / \mathrm{ft}^{2}\right)\end{array}$ & $\begin{array}{c}\text { Standard Error } \\
\left(10^{3} \mathrm{Btu} / \mathrm{ft}^{2}\right)\end{array}$ & $\begin{array}{c}\text { Relative } \\
\text { Standard } \\
\text { Error }(\%)\end{array}$ \\
\hline District steam & $92^{\mathrm{c}}$ & $(14)^{\mathrm{c}}$ & 16 \\
District hot water & $58^{\mathrm{c}}$ & $(9)^{\mathrm{c}}$ & 15 \\
District heat & $89^{\mathrm{d}}$ & $(14)^{\mathrm{C}}$ & 16 \\
District chilled water & $114^{\mathrm{c}}$ & $(19)^{\mathrm{c}}$ & 17 \\
\hline
\end{tabular}

a Source: DOE/EIA (1989) (C3ECS public-use tape), unless otherwise specified.

b Relative standard error $=($ standard error $/$ mean $\times 100)$.

c Estimated by DOE/EIA for ANL, Jan. 1994.

d Source: DOE/EIA (1992c).

- Converted from the relative standard errors given in DOE/EIA 1992c. 
TABLE 3 Characteristics of U.S. DHC Market, 1989a

\begin{tabular}{lcccc}
\hline \multicolumn{1}{c}{ Characteristic } & Steam & Hot Water & $\begin{array}{c}\text { Chilled } \\
\text { Water }\end{array}$ & $\begin{array}{r}\text { All DHC } \\
\text { Systems }\end{array}$ \\
\cline { 2 - 5 } & 81 & 18 & 24 & - \\
Number of buildings $\left(10^{3}\right)$ & 5,353 & 1,357 & 1,946 & - \\
Floor space $\left(10^{6} \mathrm{ft}^{2}\right)$ & 487 & 98 & 220 & 805 \\
Energy consumption $\left(10^{12} \mathrm{Btu}\right)$ & 3,239 & 618 & 3,073 & 6,930 \\
Energy expenditures $\left(\$ 10^{6}\right)$ & 6.64 & 6.31 & 13.97 & 8.61 \\
Average energy price $\left(\$ / 10^{6} \mathrm{Btu}\right)$ & 92 & 58 & 114 & - \\
Energy intensity $\left(10^{3} \mathrm{Btu} / \mathrm{tt}^{2}\right)$ & & & & \\
\hline
\end{tabular}

a Source: DOE/EIA (1989) (CBECS public-use tape).

\subsection{Estimation of DHC Demand by Key Market Segments}

Tables 4 through 12 provide the 1989 estimates of consumption for steam, hot water, and chilled water by selected building characteristics. Total DHC consumption was estimated to be $805 \times 10^{12}$ Btu (0.805 quad). Among the selected categories, the highest DHC shares were as follows:

- $26 \%$ for South region (Table 4),

- $30 \%$ for office buildings (Table 5),

- $22 \%$ for buildings with areas of $10,000-50,000 \mathrm{ft}^{2}$ (Table 6),

- $44 \%$ for buildings constructed in 1960 or before (Table 7 ),

- $91 \%$ for metropolitan status (Table 8 ),

- $90 \%$ for multibuilding facilities (Table 9), 
TABLE 4 DHC Energy Consumption by Census Region, 1989a

Energy Consumption (1012 Btu), by Source

\begin{tabular}{lrrrr}
$\begin{array}{l}\text { Census } \\
\text { Region }\end{array}$ & Steam & $\begin{array}{c}\text { Hot } \\
\text { Water }\end{array}$ & $\begin{array}{c}\text { Chilled } \\
\text { Water }\end{array}$ & $\begin{array}{c}\text { All } \\
\text { DHC } \\
\text { Systems }\end{array}$ \\
\hline Northeast & 164 & 15 & 26 & 205 \\
Midwest & 156 & 3 & 38 & 197 \\
South & 97 & 29 & 86 & 212 \\
West & 71 & 50 & 69 & 191 \\
All & 487 & 98 & 220 & 805 \\
\hline
\end{tabular}

a Source: DOE/EIA (1989) (CBECS public-use tape).

- $46 \%$ for private-sector ownership status (Table 10 ),

- $73 \%$ for buildings not participating in utility conservation programs (Table 11), and

- $42 \%$ for climate zone with fewer than 2,000 cooling degree-days and 5,500 or more heating degree-days (Table 12). 
TABLE 5 DHC Energy Consumption by Type of Building Activity, 1989a

Energy Consumption ( $10^{12}$ Btu), by Source

\begin{tabular}{lrrrr}
$\begin{array}{c}\text { Principal } \\
\text { Building Activity }\end{array}$ & Steam & $\begin{array}{c}\text { Hot } \\
\text { Water }\end{array}$ & $\begin{array}{c}\text { Chilled } \\
\text { Water }\end{array}$ & $\begin{array}{c}\text { All } \\
\text { DHC } \\
\text { Systems }\end{array}$ \\
\hline Office & 156 & 11 & 78 & 245 \\
Health Care & 128 & 6 & 16 & 150 \\
Education & 55 & 38 & 48 & 141 \\
Laboratory & 29 & 5 & 47 & 81 \\
Assembly & 30 & 19 & 14 & 63 \\
Lodging & 43 & 3 & 3 & 49 \\
Otherb & 47 & 16 & 14 & 77 \\
All & 487 & 98 & 220 & 805 \\
\hline
\end{tabular}

a Source: DOE/EIA (1989) (CBECS public-use tape).

b Includes the categories of mercantile services, food sales and services, public order/safety, nonrefrigerated warehouse, parking garage, and vacant.

TABLE 6 DHC Energy Consumption by Building Floor Space, $1989^{a}$

Energy Consumption (1012 Btu), by Source

\begin{tabular}{|c|c|c|c|c|}
\hline $\begin{array}{l}\text { Building } \\
\text { Floor Space } \\
\left(\mathrm{ft}^{2}\right)\end{array}$ & Steam & $\begin{array}{c}\text { Hot } \\
\text { Water }\end{array}$ & $\begin{array}{l}\text { Chilled } \\
\text { Water }\end{array}$ & $\begin{array}{c}\text { All } \\
\text { DHC } \\
\text { Systems }\end{array}$ \\
\hline 1,001 to 10,000 & 13 & 6 & 17 & 36 \\
\hline 10,001 to 50,000 & 125 & 8 & 45 & 178 \\
\hline 50,001 to 100,000 & 115 & 4 & 45 & 164 \\
\hline 100,001 to 200,000 & 72 & 34 & 61 & 167 \\
\hline 200,001 to 500,000 & 66 & 9 & 11 & 87 \\
\hline 500,001 to 1 million & 61 & 7 & 25 & 93 \\
\hline Over 1 million & 36 & 29 & 16 & 81 \\
\hline All & 487 & 98 & 220 & 805 \\
\hline
\end{tabular}

a Source: DOE/EIA (1989) (CBECS public-use tape). 
TABLE 7 DHC Energy Consumption by Building Age, 1989a

\begin{tabular}{|c|c|c|c|c|}
\hline \multirow[b]{2}{*}{$\begin{array}{c}\text { Year of } \\
\text { Construction }\end{array}$} & \multicolumn{4}{|c|}{ Energy Consumption ( $10^{12}$ Btu), by Source } \\
\hline & Steam & $\begin{array}{c}\text { Hot } \\
\text { Water }\end{array}$ & $\begin{array}{l}\text { Chilled } \\
\text { Water }\end{array}$ & $\begin{array}{c}\text { All } \\
\text { DHC } \\
\text { Systems }\end{array}$ \\
\hline 1960 or before & 247 & 39 & 66 & 352 \\
\hline 1961 to 1973 & 184 & 23 & 101 & 308 \\
\hline 1974 to 1989 & 56 & 36 & 53 & 145 \\
\hline All & 487 & 98 & 220 & 805 \\
\hline
\end{tabular}

a Source: DOE/EIA (1989) (CBECS public-use tape).

TABLE 8 DHC Energy Consumption by Metropolitan Location, $1989^{a}$

Energy Consumption (10 12 Btu), by Source

\begin{tabular}{lrrrr} 
Metropolitan Status & Steam & $\begin{array}{c}\text { Hot } \\
\text { Water }\end{array}$ & $\begin{array}{c}\text { Chilled } \\
\text { Water }\end{array}$ & $\begin{array}{c}\text { All } \\
\text { DHC } \\
\text { Systems }\end{array}$ \\
\hline $\begin{array}{l}\text { Metropolitan } \\
\text { Nonmetropolitan }\end{array}$ & 434 & 97 & 204 & 735 \\
All & 53 & 1 & 16 & 70 \\
& 487 & 98 & 220 & 805 \\
\hline
\end{tabular}

a Source: DOE/EIA (1989) (CBECS public-use tape). 
TABLE 9 DHC Energy Consumption by Multibuilding Facility Status, $1989^{a}$

Energy Consumption ( $\left.10^{12} \mathrm{Btu}\right)$, by Source

\begin{tabular}{lrrrr}
$\begin{array}{c}\text { Part of Multibuilding } \\
\text { Facility? }\end{array}$ & Steam & $\begin{array}{c}\text { Hot } \\
\text { Water }\end{array}$ & $\begin{array}{c}\text { Chilled } \\
\text { Water }\end{array}$ & $\begin{array}{c}\text { All } \\
\text { DHC } \\
\text { Systems }\end{array}$ \\
\hline Yes & 431 & 96 & 204 & 731 \\
No & 56 & 2 & 16 & 74 \\
All & 487 & 98 & 220 & 805 \\
\hline
\end{tabular}

a Source: DOE/EIA (1989) (CBECS public-use tape).

TABLE 10 DHC Energy Consumption by Building Ownership, $1989^{a}$

Energy Consumption (1012 Btu), by Source

\begin{tabular}{lrcrr} 
Ownership Status & Steam & $\begin{array}{c}\text { Hot } \\
\text { Water }\end{array}$ & $\begin{array}{c}\text { Chilled } \\
\text { Water }\end{array}$ & $\begin{array}{c}\text { All } \\
\text { DHC } \\
\text { Systems }\end{array}$ \\
\hline Federal yovernment & 34 & 32 & 26 & 92 \\
State government & 168 & 32 & 75 & 275 \\
Local government & 25 & 10 & 33 & 68 \\
Nongovernment & 260 & 24 & 86 & 370 \\
All & 487 & 98 & 220 & 805 \\
\hline
\end{tabular}

a Source: DOE/EIA (1989) (CBECS public-use tape). 
TABLE 11 DHC Energy Consumption by DSM Status, 1989a

Energy Consumption ( $10^{12}$ Btu), by Source

\begin{tabular}{cccrc}
$\begin{array}{c}\text { Participated in Utility } \\
\text { Conservation Program? }\end{array}$ & Steam & $\begin{array}{c}\text { Hot } \\
\text { Water }\end{array}$ & $\begin{array}{c}\text { Chilled } \\
\text { Water }\end{array}$ & $\begin{array}{c}\text { All } \\
\text { DHC } \\
\text { Systems }\end{array}$ \\
\hline Yes & 129 & 26 & 61 & 216 \\
No & 358 & 72 & 159 & 589 \\
All & 487 & 98 & 220 & 805 \\
\hline
\end{tabular}

a Source: DOE/EIA (1989) (CBECS public-use tape).

TABLE 12 DHC Energy Consumption by Climate Zone, 1989a

Energy Consumption (10 $12 \mathrm{Btu})$, by Source

\begin{tabular}{lrrrr}
\multicolumn{1}{c}{ Climate Zone } & Steam & $\begin{array}{c}\text { Hot } \\
\text { Water }\end{array}$ & $\begin{array}{c}\text { Chilled } \\
\text { Water }\end{array}$ & $\begin{array}{c}\text { All } \\
\text { DHC } \\
\text { Systems }\end{array}$ \\
\hline Under 2,000 CDD and 5,500 HDD or more & 243 & 43 & 55 & 341 \\
Under 2,000 CDD and 4,000-5,499 HDD & 144 & 9 & 45 & 198 \\
Under 2,000 CDD and under 4,000 HDD & 62 & 21 & 76 & 159 \\
2,000 CDD or more and under 4,000 HDD & 38 & 25 & 44 & 107 \\
All & 487 & 98 & 220 & 805 \\
\hline
\end{tabular}

a Source: DOE/EIA (1989) (CBECS public-use tape).

b $\mathrm{CDD}=$ cooling degree-days, $\mathrm{HDD}=$ heating degree-days . 


\section{DHC Market Projection Methodology}

As stated in Section 1, one of the key purposes of this research task was to estimate market penetration of steam, hot water, and chilled water in commercial buildings over a 20 -year period by using either the earlier DHC market-penetration model developed by ANL or other appropriate methodology. The steps described below were carried out to select the best option, taking into consideration the objective of the research and data availability, as well as time and financial constraints.

\subsection{Overview of Available Forecasting Methodologies}

The first step was to test the feasibility of using the DHC market-penetration model developed more than 10 years earlier by ANL. The model was restored in an "as-was" condition on a mainframe computer. (This step tested the model after almost 10 years of disuse.) This model combined an economic cost model and a diffusion model (Teotia and Raju 1986). A key reason for selecting this methodology was that the historical data on DHC applications in residential and commercial markets were not available.

In the second step, all feasible approaches were evaluated to provide the most suitable market-penetration methodology. The following methodologies, discussed in an earlier ANL report (Raju and Teotia 1985), were considered: subjective-estimation methods, market surveys, historical-analogy models, time-series models, diffusion models, economic-cost models, and discrete-choice models.

\subsection{Selected Methodology}

The econometric model was considered to be the most suitable for the objectives of the research. A key factor in the selection of this methodology was the availability of the 1989 CBECS. The econometric model uses the CBECS data to estimate the functional relationships between (1) the demand for steam, hot water, and chilled water, and (2) independent variables that influence the demand. For this study, the explanatory variables listed below were found to have a major impact on one or more demands (i.e., for steam, hot water, and/or chilled water):

- Building characteristics

- Square feet heated/cooled

- Government building 
- Building activity (office, lodging, health, assembly, laboratory, education, and other)

- Main heating energy source: steam/hot water

- Weekly operating hours

- Workers per square feet

- Number of hospital beds

- Energy cost

- Electricity price

- Steam price

- Hot-water price

- Chilled-water price

- Climate variables

- Cooling-degree days

- Energy management

- Demand-side-management (DSM) program

- Reduced use during off-hours

Some of the other key variables considered in one or more models were heating degreedays, age of building, price of natural gas, price of fuel oil, number of floors, metropolitan status, and owner/nonowner-occupancy status. None of these variables were found to be statistically significant. However, these and other variables considered to be important for demand of steam, hot water, and chilled water in commercial buildings must be retested in any updates of these models. 
The general specification of the building-energy-demand model can be represented as follows:

$$
\begin{aligned}
\log (y)=a & +\sum_{i=1}^{n} b_{i} \cdot X_{i} \\
& +\sum_{j=1}^{m} c_{j} \cdot \log \left(Z_{j}\right),
\end{aligned}
$$

where $y=$ demand for steam, hot water, or chilled water; $a, b_{i}$, and $c_{j}$ are constants; $X_{i}=$ binary independent variables, 1 if the chosen building characteristic (such as government ownership) is present, or 0 if it is not; and $Z_{j}=$ continuous independent variables, such as floor space.

Sections A.1 through A.3 in the Appendix describe the specifications of the steam, hot-water, and chilled-water models.

A special observation is made with regard to the above algebraic form of the equation. If the constant associated with the area-heated-or-cooled variable is estimated to be one, then the above model for energy consumption (Btu) will be identical to the model for energy intensity $\left(\mathrm{Btu} / \mathrm{ft}^{2}\right)$.

Remarkably, Tables A.1 through A.3 in the Appendix show that the estimated coefficient for the area-heated variable is 0.99 for district steam, 0.98 for district chilled water, and 0.84 for district hot water. Therefore, these energy consumption models are extremely close approximations for steam and chilled water and a close approximation for hot water. 


\section{Characterization of DHC Base Case}

The model described in the Appendix was used to estimate DHC market penetration under the base case. In the first step, the explanatory variables were projected into the future, as described below.

\subsection{DHC Technology and End-Use Market Assumptions under the Base Case}

Variables discussed in this section are technology improvements (Section 5.1.1), institutional factors (Section 5.1.2), and demand-side-management programs (Section 5.1.3). All three are expected to influence future DHC market penetration.

\subsubsection{Technology Improvements}

The Department of Energy has been a major contributor in the development of DHC systems and in the revitalization of older systems. Since 1980, DOE has sponsored research in partnership with industry and the utility sector to develop new technologies and to improve the performance of existing technologies for DHC systems. DOE's DHC research program has funded research in ice storage and ic's slurries and friction-reduction additives for thermal distribution systems. These research efforts could have a major impact in the future, increasing the efficiency and cost-effectiveness of district heating and cooling systems. A preliminary economic assessment of the ice-slurry research, conducted at ANL, indicates that when a $30 \%$ ice slurry is used in place of chilled water, the cost of DC distribution systems could be reduced by as much as 50\% (Kasza and Chen 1987). Other research project: have focused on acoustic leak detection, piping insulation, meters to measure steam usage, advanced heat pumps, and low-cost Btu meters. Computer software to conduct feasibility studies has also been developed for the purpose of identifying technically and economically feasible DHC systems. These research efforts will enhance the technical and economic performance of DHC systems in the future. To capture the effect of these changes, it was assumed that the real (inflation-adjusted) price of chilled water could be reduced by about $25 \%$ over the next 20 years.

\subsubsection{Institutional Factors}

District heating and cooling systems face a number of economic, financial, and institutional problems that, in the past, impeded their ability to compete on an equal footing with other sources of energy, particularly with oil and natural gas. These impediments include the lack of data and information that have resulted in DHC systems not being fully considered by decision makers. National DHC market statistical data have not been documented by industry groups, making it 
difficult for the industry and key decision makers to identify and assess market opportunities for developing new DHC systems.

From the federal government's perspective, the lack of industry market statistics has also made it difficult for DOE to prioritize activities aimed at enhancing the penetration of DHC systems.

Other major barriers to DHC development are the high cost of building a new system, the taxes and fees that add to the costs, and the requirements that potential investors place on loans. These impediments have affected the development of large urban DHC systems and, to a lesser extent, that of the smaller, nonprofit municipal DHC systems.

DHC systems offer important environmental benefits and energy-conservation potential; many DHC systems can use locally produced fuels, such as biomass and geothermal energy, and can operate annually at higher efficiencies than can individual-building heating and cooling equipment. Further, DHC plants can benefit the environment by replacing individual-building heating equipment, which, very often, collectively emits much higher levels of greenhouse gases into the atmosphere than does a single, well-maintained DHC plant.

Today, because of the lack of adequate, reliable data on the national DHC market, it is difficult to document the advantages of DHC and to persuade government and private-sector decision makers to support DHC development. This ANL study, aimed at estimating the DHC market (including DHC systems data-gathering activities at Oak Ridge National Laboratory, with industry collaboration), would provide key information that would help stimulate market growth and product development. In this favorable environment, under the base case, market penetration of DHC systems should be determined increasingly on the basis of their relative merits with respect to other competitive systems.

\subsubsection{DSM Programs}

Demand-side-management programs, sponsored by electric utilities and approved by state and local regulating authorities, are designed to defer the growth of power-generating capacity and to increase the utilization factor of existing power-generating facilities. This innovative approach to managing electric-power demand, by providing incentives to end-users for reducing their electricpower demand requirements, has also increased the market opportunities for district cooling and cogeneration. By switching to district cooling, a large commercial building may reduce substantially the high cost of on-peak demand charges typically charged by electric utilities during peak demand periods. DSM programs have also contributed to the implementation of cogeneration systems in many existing and new DHC installations.

Real prices of natural gas and crude oil have declined in the last few years. In some parts of the United States, cogeneration developers have been able to secure long-term supplies of 
reasonably priced natural gas. The availability of low-cost fuel and the DSM programs are major factors in the dramatic increase in cogeneration development in the industrial sector. Another important factor in the wide use of cogeneration systems is the improvement in efficiency and reliability of medium-size (less than $50 \mathrm{MW}$ ) cogeneration systems. In the future, these DSM programs are expected to contribute to the growth of DHC systems.

\subsection{Projections of DHC Model Exogenous Variables under the Base Case}

The explanatory variables used in the steam, hot-water, and chilled-water models are listed in Tables A.1 through A.3 in the Appendix. Projection of each of these variables is needed in order to project consumption of steam, hot water, and chilled water in a building. For simplicity, it was assumed that the distribution of buildings as characterized in the 1989 CBECS data set was applicable for the forecast period. Sections 5.2.1 through 5.2.3 provide specific discussion on some of the key explanatory variables. Section 5.2.4 discusses the remaining variables.

\subsubsection{Commercial-Building Floor Space}

One of the most important variables for future growth of DHC systems is the construction of commercial buildings. As discussed in the Appendix, the area-heated variable (SFHEAT) is statistically the most significant variable in the steam and hot-water models. Similarly, the areacooled variable (SFCOOL) is the most significant variable in the chilled-water model.

The area heated and the area cooled were projected at the same rates as those in DOE's Annual Energy Outlook 1992 projections of total floor space in the commercial sector between 1990 and 2010 (DOE/EIA 1992a).

\subsubsection{Commercial-Sector Electricizy Price}

The projections of the average price of electricity in the commercial sector between 1990 and 2010 were taken from the DOE's Annual Energy Outlook 1992 (DOE/EIA 1992a). The electricity-price variable (LPEL) in the model was projected accordingly.

\subsubsection{Prices of Steam, Hot Water, and Chilled Water}

The price of steam in the steam model and the price of chilled water in the chilled-water model were found to be statistically significant in explaining their own consumption in a building (see Appendix). However, the hot-water price variable was found to be not statistically significant 
in explaining the consumption of hot water. This result could be attributed to the relatively fewer observations for buildings using hot water than for buildings using either steam or chilled water.

Given the lack of published price projections for district steam, hot water, and chilled water, certain assumptions had to be made. Because the technologies used in steam systems are relatively mature, it was assumed that current prices of steam (PST) will escalate at the rate of inflation in the U.S. economy (i.e., the prices in constant 1989 dollars will remain the same during the forecast period).

As discussed in Section 5.1.1, changes in district chilled-water technology, such as iceslurry systems and ice storage, are expected to lower the cost of chilled-water systems by about $25 \%$ over the next 20 years. To reflect this trend, the price of chilled water (PCW) in constant dollars was reduced by about $1 \%$ annually between 1990 and 2010 .

\subsubsection{Other Exogenous Variables}

Several dummy variables are included in each of the steam, hot-water, and chilled-water models. In the CBECS-based sample for the analysis, these dummy variables take the value of 1 or 0 , depending on their applicability to a particular building. These dummy variables are government building [GOV], steam as the main heating energy source [DV1], hot water as the main heating energy source [DV2], participation in the utility DSM program [DV4], reduced use of heating and cooling during off-hours (DVRDHC), and principal activity of the buildings [ACT2, ACT4, ACT5, ACT6, ACT7, and ACT8]). The average value of each of these dummy variables was estimated by using the 1989 CBECS data set and was assumed to remain unchanged during the 1990-2010 forecast period. This average value is equivalent to the probability of a building being of that type. For example, for variable DV1, the average value is equivalent to the probability of a building using steam as a main space-heating energy source.

For any of the following variables, no change was made during the forecast period: cooling degree-days (CDAY), workers per square foot (WKFS), weekly operating hours (WKHRS), and number of hospital beds (HCCBED). 


\section{DHC Market Projections under the Base Case}

The consumption of district steam, hot water, and chilled water in commercial buildings was projected for the $1990-2010$ period by using the DHC model under the base case as described in Section 5. Projections have been made for the five categories of DHC system types described in Section 2. In this section, national projections are discussed first; then projections for selected DHC systems are presented.

\subsection{National Market Projections}

Table 13 provides the projections for steam, hot water, and chilled water for the years 2000 and 2010. The highlights are as follows:

- The total annual consumption of steam, hot water, and chilled water will approach about 1 quad (1015 Btu) by the year 2000 and 1.25 quad by 2010 .

- Between 1989 and 2010, the cumulative percentage change in the demand for chilled water will be almost twice the changes in the demands for steam and hot water.

- The chilled-water market will double during the forecast period.

TABLE 13 DHC Market Projections under the Base Case

\begin{tabular}{|c|c|c|c|c|}
\hline \multirow{2}{*}{$\begin{array}{l}\text { Energy } \\
\text { Source }\end{array}$} & \multicolumn{3}{|c|}{$\begin{array}{l}\text { Energy Consumption } \\
\left(10^{12} \mathrm{Btu}\right) \text {, by Year }\end{array}$} & \multirow{2}{*}{$\begin{array}{l}\text { Change (\%) } \\
1989-2010\end{array}$} \\
\hline & $1989^{a}$ & 2000 & 2010 & \\
\hline Steam & 487 & 582 & 690 & 42 \\
\hline Hot water & 98 & 120 & 141 & 44 \\
\hline Chilled water & 220 & 298 & 399 & 82 \\
\hline Total & 805 & 1,000 & 1,231 & 53 \\
\hline
\end{tabular}

a Source: DOE/EIA (1989) (CBECS public-use tape). 


\subsection{Market Projections for Selected DHC Systems}

\subsubsection{DHC System Type I}

For the first application, the CBECS database was used to estimate the consumption of steam, hot water, and chilled water in educational, health-care, and government-owned buildings in 1989. On the basis of the 1989 IDHCA survey (IDHCA 1989) discussed in Section 3.3, ANL estimated that $96 \%$ of total (Btu) sales of steam, hot water, chilled water, and cogenerated electricity was associated with the DHC systems with no electricity sales to the grid. This percentage was used in estimating the 1989 consumption of steam, hot water, and chilled water from the DHC systems with no electricity sales to the grid serving educational, health-care, and government building complexes (Table 14). The projections for steam, hot water, and chilled water for the years 2000 and 2010 were made by using the model. The total consumption of steam, hot water, and chilled water is projected to grow from about $520 \times 10^{12} \mathrm{Btu}$ in 1989 to $800 \times 10^{12}$ Btu in 2010 .

\subsubsection{DHC System Type II}

For the second application, the CBECS database was used to estimate the consumption of steam, hot water, and chilled water in multibuilding facilities in metropolitan areas in 1989. On the basis of the 1989 IDHCA survey (IDHCA 1989) discussed in Section 3.3, ANL estimated that $77 \%$ of steam, $37 \%$ of hot-water, and $16 \%$ of chilled-water sales were accounted for by the large DHC systems. These percentages were used in estimating the 1989 consumption of steam, hot water, and chilled water from the large DHC systems (Table 15). The projections for steam, hot

TABLE 14 DHC Energy Consumption Projections for Educational, Health-Care, and GovernmentOwned Buildings

\begin{tabular}{|c|c|c|c|c|}
\hline \multirow{2}{*}{$\begin{array}{l}\text { Energy } \\
\text { Source }\end{array}$} & \multicolumn{3}{|c|}{$\begin{array}{l}\text { Energy Consumption } \\
\left(10^{12} \mathrm{Btu}\right) \text {, by Year }\end{array}$} & \multirow{2}{*}{$\begin{array}{l}\text { Cumulative } \\
\text { Change (\%), } \\
1989-2010\end{array}$} \\
\hline & 1989 & 2000 & 2010 & \\
\hline Steam & 298 & 356 & 422 & 42 \\
\hline Hot water & 78 & 95 & 112 & 44 \\
\hline Chilled water & 146 & 203 & 271 & 85 \\
\hline All & 522 & 653 & 805 & 55 \\
\hline
\end{tabular}


TABLE 15 DHC Energy Consumption Projections for Multibuilding Facilities in Metropolitan Areas and Those Served by Large DHC Systems

\begin{tabular}{|c|c|c|c|c|}
\hline \multirow{2}{*}{$\begin{array}{l}\text { Energy } \\
\text { Source }\end{array}$} & \multicolumn{3}{|c|}{$\begin{array}{l}\text { Energy Consumption } \\
\left(10^{12} \text { Btu }\right) \text {, by Year }\end{array}$} & \multirow{2}{*}{$\begin{array}{l}\text { Cumulative } \\
\text { Change (\%), } \\
1989-2010\end{array}$} \\
\hline & 1989 & 2000 & 2010 & \\
\hline Steam & 292 & 350 & 415 & 42 \\
\hline Hot water & 38 & 47 & 55 & 44 \\
\hline Chilled water & 37 & 51 & 68 & 84 \\
\hline All & 367 & 447 & 538 & 47 \\
\hline
\end{tabular}

water, and chilled water for the years 2000 and 2010 were made by using the model. The total consumption of steam, hot water, and chilled water is projected to grow from about $370 \times 10^{12}$ Btu in 1989 to about $540 \times 10^{12}$ Btu in 2010 .

\subsubsection{DHC System Type III}

For the third application, the CBECS database and the model were used to estimate past and future consumption of district cooling systems (Table 13). These projections are discussed in Section 6.1 .

\subsubsection{DHC System Types IV and V}

The Department of Energy was also interested in market projections of two other systems: (1) Independent Power Producers (IPP) and Qualifying Facilities (QF) under PURPA, with cogeneration facilities and grid connection, and (2) medium-sized DHC systems deriving thermal energy from utility-owned or municipally owned facilities, retrofitted to DHC power plants and serving multiple end-users in urban areas. In this regard, the projections of the IPP and cogeneration systems were available from Data Resources, Inc. (DRI 1992), and are shown in Table 16. The total market potential of DHC system Type IV is estimated to increase from about $440 \times 10^{12}$ Btu in 1990 to $550 \times 10^{12}$ Btu in 2010 .

No projections were made for the retrofitting of utility-owned generating plants to cogeneration, because only a very small market was expected. This conclusion was made on the basis of experience indicating that utilities have not become a key player in new DHC systems. 
TABLE 16 Estimated Market Potential of DHC System Type IV

\begin{tabular}{|c|c|c|c|}
\hline \multirow[b]{2}{*}{ Generators/Sources } & \multicolumn{3}{|c|}{ Installed Capacity $\left(10^{3} \mathrm{MW}\right)$, by Decade } \\
\hline & 1990 & 2000 & 2010 \\
\hline $\begin{array}{l}\text { Cogenerators, total } \\
\text { Oillnatural gas } \\
\text { Coal } \\
\text { Other }\end{array}$ & $\begin{array}{r}28 \\
15 \\
5 \\
8\end{array}$ & $\begin{array}{r}42 \\
22 \\
8 \\
13\end{array}$ & $\begin{array}{l}49 \\
24 \\
10 \\
16\end{array}$ \\
\hline $\begin{array}{l}\text { Independent Power Producers (IPP), total } \\
\text { Oil/natural gas } \\
\text { Coal } \\
\text { Other }\end{array}$ & $\begin{array}{r}20 \\
3 \\
1 \\
16\end{array}$ & $\begin{array}{r}28 \\
4 \\
2 \\
22\end{array}$ & $\begin{array}{r}28 \\
4 \\
2 \\
22\end{array}$ \\
\hline $\begin{array}{l}\text { Total Nonutility Generators' (NUG) } \\
\text { Capacity } \\
\text { Output/Potential }\end{array}$ & 48 & 70 & 77 \\
\hline IPP Electricity Output $\left(10^{9} \mathrm{kWh}\right)^{\mathrm{a}}$ & 87 & 107 & 108 \\
\hline DHC Potential (1012 Btu) ${ }^{a}$ & 440 & 541 & 546 \\
\hline
\end{tabular}

a Source: Based on ANL estimates.

Source (unless otherwise noted): DRI (1992). 


\section{Conclusions}

\subsection{Overview and Scope}

Historically, the DHC market in the United States has not been well-documented. Over the years, the DHC industry has not collected and maintained reliable statistical information on all segments of the U.S. DHC market. As a result, only limited data are available on the population of DHC systems, including the DHC share of the space heating and cooling market and the systems' technical and economic performance. DHC organizations have conducted surveys to collect DHC data; however, such data represent some segments of the market better than others. The lack of credible DHC market data has made it difficult to assess the DHC systems' national energyconservation and environmental benefits and to develop and justify actions to enhance the market penetration of DHC systems.

The market study conducted by ANL and sponsored by DOE, with support from the industry, was to provide information on the existing DHC market and project its growth potential to the year 2010. The success of this market study was highly dependent on the availability and collection of reliable statistical information from industry and government sources, including information developed through industry interactions.

A major effort in this study was also directed toward identifying and developing information on emerging trends that are likely to have a major impact on the economics and market penetration of existing and future DHC systems. Some typical institutional factors that were identified in this study with potential for affecting the future growth of DHC systems were the phasing out of CFCs, electric-utility demand-side-management programs, environmental regulations, and changing attitudes of financial institutions in assigning risks for DHC capital investments. These factors are recognized by the industry as important positive trends for future DHC growth; however, because of their recent emergence, very little is known quantitatively about their potential contributions to the development and market penetration of DHC systems. Attempts have been made in this study to incorporate these emerging factors into the model for projecting the DHC growth potential.

Technology-driven cost-reduction contributions to DHC systems, important especially to DC systems, were identified as major elements in DHC market growth. DOE-sponsored research in ice-water slurries has the potential of substantially reducing the up-front capital cost of new DC distribution systems. These future improvements in DC technologies are contributing to the projected increased market penetrations of DC systems. 


\subsection{Application of the Model}

The primary objective of the research reported here was to estimate the market penetration of DHC systems to the year 2010. The first step in the analysis was to conduct a literature search to identify major data sources on historical DHC markets and any models for forecasting DHC markets. The collected information verified that no research providing national market projections of DHC systems had been undertaken during the last 10 years.

Major improvements were noted with regard to the availability of historical data on consumption and expenditures for district steam, hot water, and chilled water through DOE/EIA Commercial Buildings Energy Consumption Surveys conducted for 1979, 1983, 1986, and 1989. On the basis of an evaluation of the available data and methodologies for estimating market penetration of new technologies, ANL investigators concluded that a new econometric model should be developed for forecasting DHC markets.

By using the 1989 CBECS data, parameters were estimated by means of the ordinary leastsquare (OLS) methodology for each of the three equations for steam, hot-water, and chilled-water demand in the buildings surveyed. The model was used to project consumption of district steam, hot water, and chilled water in buildings in the years 2000 and 2010.

\subsection{Principal Findings}

The analysis has shown that the total U.S. market for district steam, hot water, and chilled water could grow from 0.8 quad in 1989 to 1.0 quad by the year 2000 and 1.25 quad by 2010 . A key assumption in this analysis is that, because of improvements in technology, the effective cost of chilled water can be reduced by $20 \%$ over the forecast period. The demand for chilled water could nearly double in the forecast period, and its share could approach one-third of the total DHC market.

\subsection{Limitations and Utility of the Model}

Some limitations of the DHC model developed under this study are noted. First, there is a limited number of observations (in 1989 CBECS) on the buildings using steam, hot water, and chilled water, which imposes restrictions on the specification of the model. Second, unlike the steam and chilled-water models, the records where DOE/EIA had imputed values for hot-water consumption by using their regression equation were not eliminated from the CBECS data set used for estimating parameters of the hot-water model, because there would have been too few cases for hot water in the sample. As noted in Section A.2, the effect of including the imputed hot-waterconsumption data on estimation of key coefficients appears to be minimal. In any update, however, the number of cases, at least for hot water, should be increased by pooling the 1989 CBECS data with other compatible CBECS data. 
This model should be of interest to policymakers, researchers, and market participants involved with planning and implementing energy-conserving and environmentally beneficial district energy systems. 


\section{References}

Data Resources, Inc., 1992, Energy Review: Second Quarter 1992, Lexington, Mass.

Electric Power Research Institute, 1990, Cogeneration and Independent Power Production: Market Insight and Outlook, Electric Power Research Institute report EPRI CU-6964, Palo Alto, Calif., Aug.

Gas Research Institute, 1982, Natural Gas Based Cogeneration Market Potential, Gas Research Institute report GRI-80/0102, Chicago, Ill.

International District Heating Association (IDHA), 1983, District Heating Handbook, Fourth Edition, Vol. 1, Washington, D.C.

International District Heating and Cooling Association (IDHCA), 1989, 1989 District Heating and Cooling Industry Statistics Report, New York, N.Y.

Kasza, K.E., and M.M. Chen, 1987, Assessment of Impact of Advanced Energy Transmission Fluids on District Heating and Cooling Systems (Phase I), Argonne National Laboratory report ANL-87-21, Argonne, Ill., Sept.

Raju, P., and A.P.S. Teotia, 1985, An Evaluation of Market Penetration Forecasting Methodologies for New Residential and Commercial Energy Technologies, Argonne National Laboratory report ANL/EES-TM-315, Argonne, III.

RCG/Hagler, Bailly, Inc., 1990, Profile IV: Independent Power Market-Status and Trends, Washington, D.C., Jan.

Teotia, A.P.S., and P. Raju, 1986, "Forecasting the Market Penetration of New Technologies Using a Combination of Economic Cost and Diffusion Models," Journal of Product Innovation Management 3(4):225-237.

Teotia, A.P.S., A.A. Davis, and D. Poyer, 1981, Cogeneration Energy Systems Show Promoting Market Potential in Residential and Commercial Sector Over Next 25 Years, Proc. 16th Intersociety Energy Conversion Engineering Conf., American Society of Mechanical Engineers, New York, N.Y.

Teotia, A.P.S., and D. Poyer, 1983, Macroeconomic Effects under the Proposed District Heating and Cooling Tax Incentives Act of 1982, Argonne National Laboratory report ANL/CNSV-TM155, Argonne, Ill. 
U.S. Department of Energy/Energy Information Administration, 1989, Commercial Buildings Consumption and Expenditures: 1986, report DOE/EIA-0318(86), Washington, D.C., May.

U.S. Department of Energy/Energy Information Administration, 1992a, Annual Energy Outlook 1992: With Projections to 2010, report DOE/EIA-0383(92), Washington, D.C., Jan.

U.S. Department of Energy/Energy Information Administration, 1992b, "DOE/EIA 1989 Commercial Buildings Energy Consumption Survey," public-use tape, June.

U.S. Department of Energy/Energy Information Administration, 1992c, Commercial Buildings Energy Consumption and Expenditures: 1989, report DOE/EIA-0318(89), Washington, D.C., April.

U.S. Department of Energy/Energy Information Administration, 1992d, "Mean and Relative Standard Error Estimates for Chilled Water," provided to Argonne National Laboratory, July.

U.S. Department of Energy/Energy Information Administration, 1993. Assessment of Energy Use in Multibuilding Facilities, report DOE/EIA-0555(93)/1, Aug.

U.S. Department of Energy/Energy Information Administration, 1994, "Estimates of Means and Relative Standard Errors for Steam, Hot Water, and Chilled Water," provided to Argonne National Laboratory, Jan. 


\section{Appendix:}

\section{Development of DHC Models}

In Section 1, it was pointed out that one of the key purposes of this research task was to estimate market penetration of steam, hot water, and chilled water in commercial buildings to the year 2010 by using either the earlier DHC market-penetration model developed by ANL or other, more appropriate methodologies. The steps described below were carried out to select the best option, taking into consideration the objective of the research and data availability, as well as time and financial constraints.

The first step was to test the feasibility of using the DHC market-penetration model developed by ANL between 1979 and 1981. The model was restored in an "as-was" condition on a mainframe computer. (This step tested the model after almost 10 years of disuse.) This model combined an economic cost model and a diffusion model (Teotia and Raju 1986). A key reason for selecting this methodology was that the historical data on DHC applications in residential and commercial markets were not available.

In the second step, all feasible approaches were evaluated to provide the most suitable market-penetration methodology. The following methodologies, discussed in an earlier ANL report (Raju and Teotia 1985), were considered: subjective-estimation methods, market surveys, historical-analogy models, time-series models, diffusion models, economic-cost models, and discrete-choice models.

The econometric model was considered to be the most suitable for the objectives of the research. A key factor in the selection of this methodology was the availability of the 1989 CBECS. The econometric model uses the CBECS data to estimate the functional relationships between (1) the demand for steam, hot water, and chilled water and (2) independent variables that influence the demand. The CBECS data set included 539 records for buildings that use steam, hot water, and/or chilled water. The explanatory variables found to have a major impact on one or more demands (i.e., for steam, hot water, and/or chilled water) are listed in Section 4.2. follows:

The general specification of the building-energy-demand model can be represented as

$$
\begin{aligned}
\log (y)=a & +\sum_{i=1}^{n} b_{i} \cdot X_{i} \\
& +\sum_{j=1}^{m} c_{j} \cdot \log \left(Z_{j}\right),
\end{aligned}
$$


where $y=$ demand for steam, hot water, or chilled water; $a, b_{i}$, and $c_{j}$ are constants; $X_{i}=$ binary independent variables, 1 if the chosen building characteristic (such as government ownership) is present, or $\mathbf{0}$ if it is not; and $\mathrm{Z}_{\mathbf{j}}=$ continuous independent variables, such as floor space.

Sections A.1 through A.3 describe the specifications of the steam, hot-water, and chilled-water models.

\section{A.1 Steam Demand Model}

Before estimation of the model, the cases where DOE/EIA had imputed values for steam consumption by using their regression equation were eliminated from the CBECS data set. Table A.1 shows the ordinary least-squares (OLS) parameter estimates based on this CBECS data subset. The model has six binary variables: government ownership (GOV), steam as the main heating energy source (DV1), participation in the utility DSM program (DV4), and the principal activity of the building - laboratory (ACT2), health care (ACT4), or other (ACT8). Additionally, the model has four continuous variables: square feet heated (LSFHEAT), workers per square foot (LWKFS), electricity price (LPEL), and steam price (LPST). All explanatory variables have the correct sign. The variables LPST, LSFHEAT, and ACT4 are statistically the most significant (all have a t-ratio of $<-2$ or $>2$, corresponding to $95 \%$ confidence levels). The regression equation explains about $67 \%$ of the variation in building steam demand.

\section{A.2 Hot-Water Demand Model}

Table A.2 shows the OLS parameter estimates, which are based on the CBECS data subset. The model has four binary variables: hot water as the main heating energy source (DV2), participation in the utility DSM program (DV4), reduced use during off-hours (DVRDHC), and education as the principal activity of the building (ACT7). Additionally, the model has four continuous variables: square feet heated (LSFHEAT), weekly operating hours (LWKHFS), workers per square foot (LWKFS), and number of hospital beds (LHCCBED). All explanatory variables have the correct sign. The variables LSFHEAT, LWKFS, and DV2 are statistically the most significant, with a t-ratio of $<-2$ or $>2$. The regression equation explains about $91 \%$ of the variation in building hot-water demand.

The cases where DOE/EIA had imputed values for hot-water consumption by using their regression equation were not eliminated from the CBECS data set before estimation of the model, because there were too few cases in the sample. Therefore, this estimated model should be used with utmost care. The effect of any of the variables (such as area in square feet) included in the DOE/EIA regression equation will be artificially strong. However, the magnitude and the t-ratio (measuring statistical-significance level) estimated for the key area coefficient in the above hotwater model are very close to those in the steam model (Tables A.1 and A.2). Therefore, the 
TABLE A.1 OLS Parameter Estimates for District Steam Demand Modela

\begin{tabular}{|c|c|c|c|c|}
\hline Parameter & Symbol & Estimate & $\begin{array}{l}\text { Standard Error } \\
\text { of Estimate }\end{array}$ & t-Ratio \\
\hline Intercept & INT & -1.174 & 1.117 & -1.05 \\
\hline $\begin{array}{l}\text { Building ownership, } \\
\text { government }\end{array}$ & Govo & 0.209 & 0.171 & 1.22 \\
\hline $\begin{array}{l}\text { Building main heating energy source, } \\
\text { steam }\end{array}$ & $D V 1^{b}$ & 0.510 & 0.369 & 1.38 \\
\hline $\begin{array}{l}\text { Participated in utility DSM program } \\
\text { Principal building activity }\end{array}$ & DV4b & 0.127 & 0.180 & 0.70 \\
\hline Laboratory & ACT2 $2^{b}$ & 0.760 & 0.428 & 1.78 \\
\hline Health care & ACT4 ${ }^{b}$ & 0.799 & 0.263 & 3.04 \\
\hline Other & АСТ $8^{b}$ & 0.306 & 0.277 & 1.10 \\
\hline $\log$ (workers $/ \mathrm{ft}^{2}$ ) & LWKFS & 0.114 & 0.063 & 1.81 \\
\hline $\log \left(t^{2}\right.$ heated) & LSFHEAT & 0.991 & 0.058 & 17.05 \\
\hline Log (electricity price) & LPEL & 0.120 & 0.237 & 0.50 \\
\hline Log (steam price) & LPST & -1.014 & 0.191 & -5.31 \\
\hline Log (steam demand) & LQSTEAM & & pendent variable) & \\
\hline
\end{tabular}

$R^{2}=0.667$

b Binary variable (yes $=1$, no $=0$ ).

TABLE A.2 OLS Parameter Estimates for District Hot-Water Demand Modela

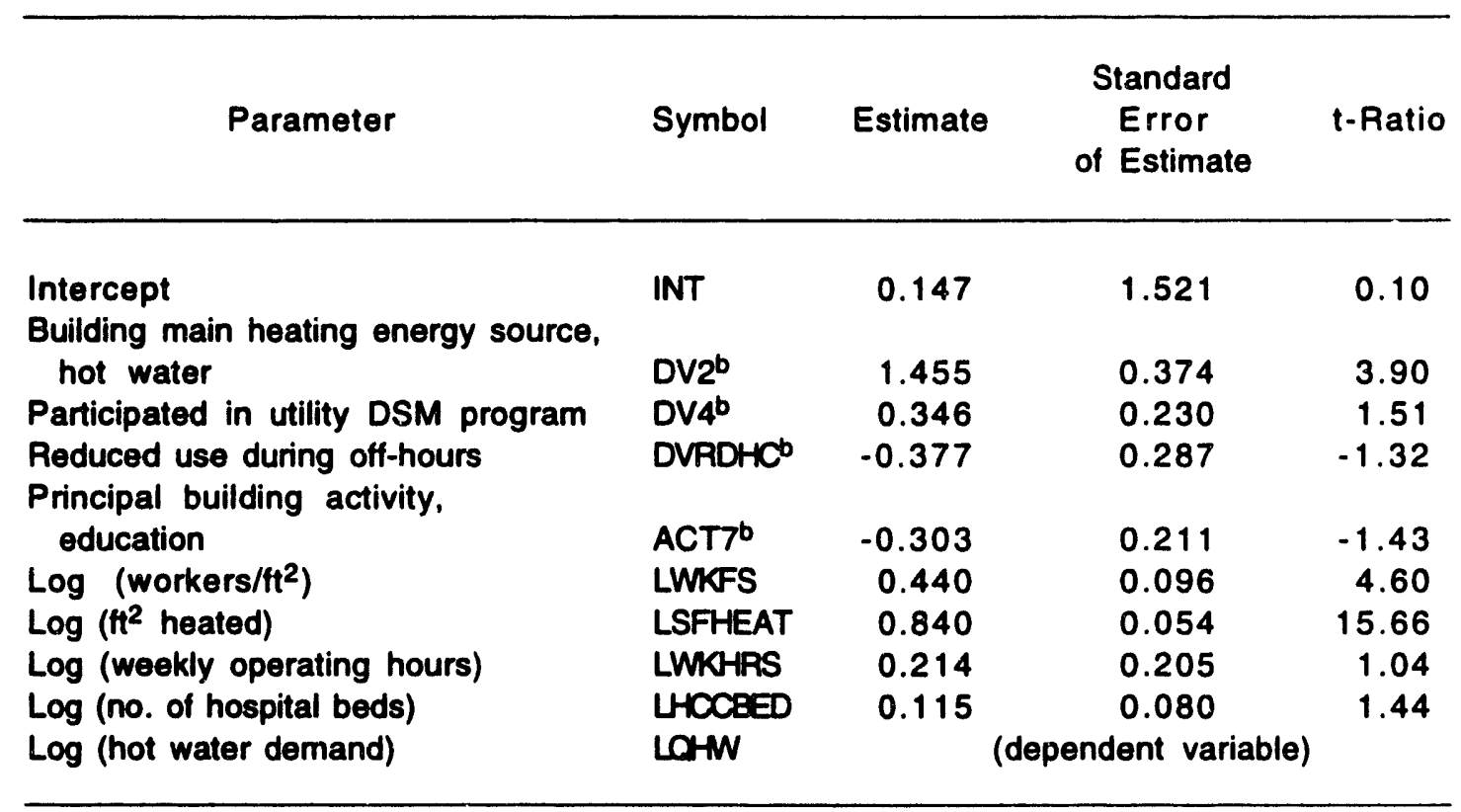

$\mathrm{R}^{2}=0.917$

b Binary variable (yes $=1$, no $=0$ ). 
effect of the inclusion of imputed hot-water consumption data on the estimation of key coefficients appears to be minimal. However, in any update, the number of cases in the sample should be increased by pooling the 1989 CBECS data with other compatible CBECS data.

\section{A.3 Chilled-Water Demand Model}

Before estimation of the model, the cases where DOE/EIA had imputed values for chilledwater consumption by using their regression equation were eliminated from the CBECS data set. Table A.3 shows the OLS parameter estimates, which are based on this CBECS data subset. The model has four binary variables: government ownership (GOV), principal activity of the building assembly (ACT5), lodging (ACT6), or other (ACT8). Additionally, the model has four continuous variables: square feet cooled (LSFCOOL), weekly operating hours (LWKHRS), cooling degreedays (LCDAY), and chilled-water price (LPCW). All explanatory variables have the correct sign. The variables LSFCOOL, LPCW, LWKHRS, and the intercept term (INT) are statistically the most significant, with a t-ratio of $<-2$ or $>2$. The regression equation explains about $77 \%$ of the variation in the building chilled-water demand.

TABLE A.3 OLS Parameter Estimates for District Chilled-Water Demand Modela

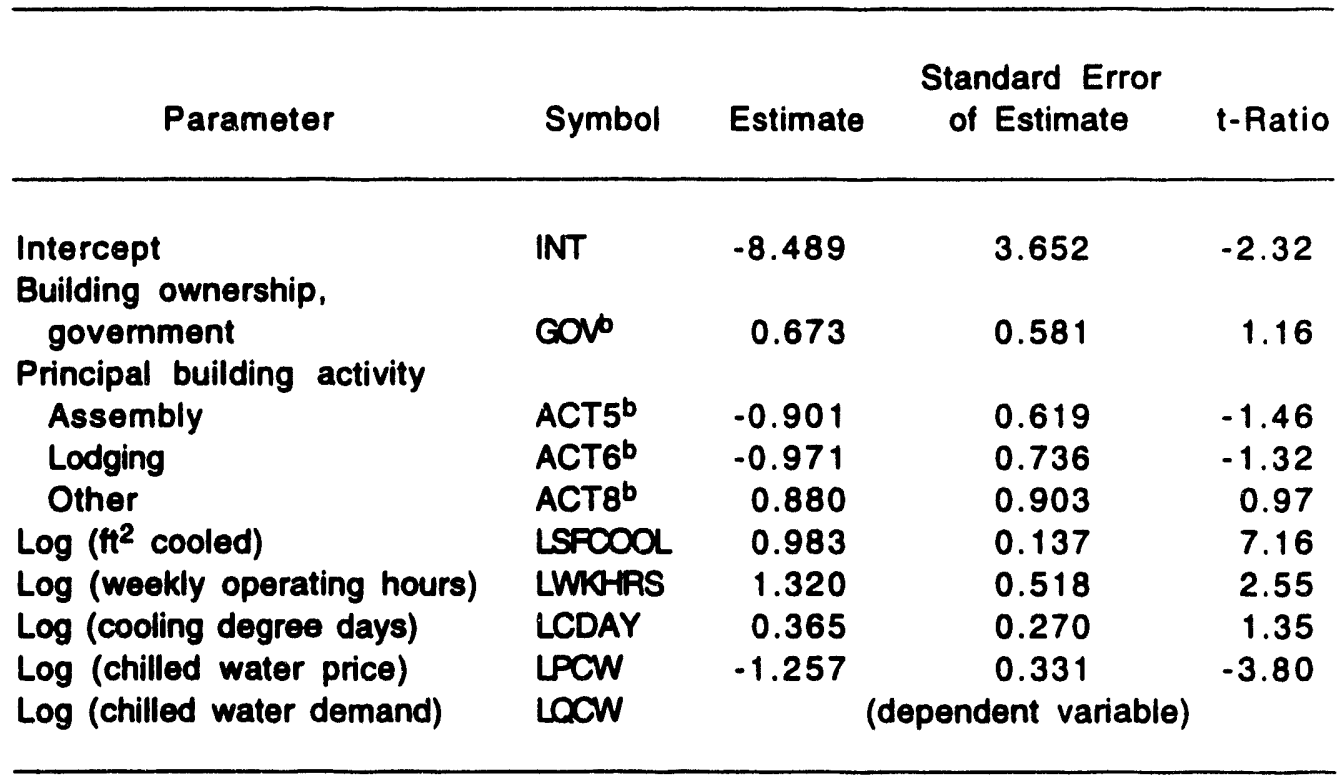

$R^{2}=0.771$.

b Binary variable (yes $=1$, no $=0$ ). 


\section{Distribution for ANL/ESD-21}

Internal

$\begin{array}{ll}\text { ANL Technical Publications Services } & \text { R. Weeks } \\ \text { N. Clodi (4) } & \text { F. Bennett }\end{array}$

A.P.S. Teotia (77)

\section{External}

U.S. Department of Energy Office of Scientific and Technical Information (12)

Manager, U.S. Department of Energy Chicago Field Office

ANL-E Libraries (2)

ANL-W Library 

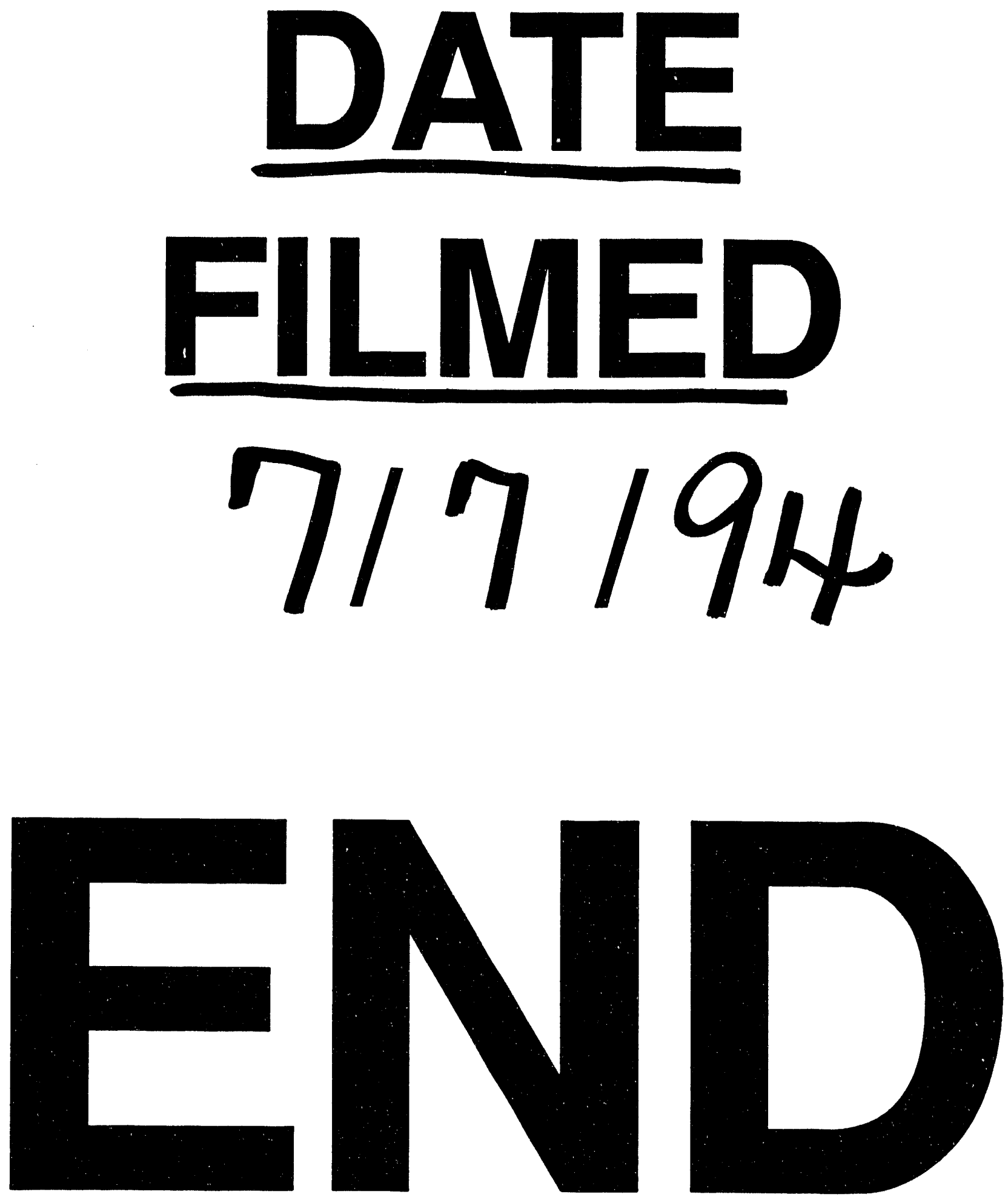
